Abstracta Iranica Abstracta Iranica

Revue bibliographique pour le domaine irano-aryen

Volume 23 | 2002

Comptes rendus des publications de $\mathbf{2 0 0 0}$

«Coinage in the name of Yazdgerd III (AD 632-651)

and the Arab conquest of Iran ». The Numismatic

Chronicle, 160, (2000), pp. 135-170, pl. 13-29.

Karin Mosig-Walburg

(2) OpenEdition

12 Journals

Édition électronique

URL : http://journals.openedition.org/abstractairanica/35325

DOI : 10.4000/abstractairanica.35325

ISSN : 1961-960X

Éditeur :

CNRS (UMR 7528 Mondes iraniens et indiens), Éditions de l'IFRI

Édition imprimée

Date de publication : 15 mai 2002

ISSN : 0240-8910

Référence électronique

Karin Mosig-Walburg, " " Coinage in the name of Yazdgerd III (AD 632-651) and the Arab conquest of

Iran ». The Numismatic Chronicle, 160, (2000), pp. 135-170, pl. 13-29. », Abstracta Iranica [En ligne],

Volume 23 | 2002, document 106, mis en ligne le 08 février 2010, consulté le 25 septembre 2020.

URL : http://journals.openedition.org/abstractairanica/35325 ; DOI : https://doi.org/10.4000/

abstractairanica.35325

Ce document a été généré automatiquement le 25 septembre 2020

Tous droits réservés 


\title{
" Coinage in the name of Yazdgerd III (AD 632-651) and the Arab conquest of Iran $»$. The Numismatic Chronicle, 160, (2000), pp. 135-170, pl. 13-29.
}

\author{
Karin Mosig-Walburg
}

1 Sur la base des monnaies peu nombreuses de Yazdgerd III et des sources antiques, l'auteur essaie d'élucider l'histoire de la conquête de l'Iran par les Arabes. Elle aborde le problème des sources et entreprend une étude approfondie des monnaies, consacrant un chapitre spécial aux monnaies de Kirmân. Elle arrive à la conclusion qu'on ne peut reconstruire toute la chronologie de la conquête arabe sur la base du monnayage de Yazdgerd III. On peut toutefois en déduire que Yazdgerd III était un roi faible dès le commencement de son règne, et qu'il perdit contrôle après la bataille de al-Qâdisiyyah. Le système monétaire change pendant les années 19 et 20, les dates devenant peut-être immobiles, et la question demeure ouverte de savoir par qui les monnaies ont été émises : les Arabes ou des gouverneurs encore loyaux à Yazdgerd III ? Les monnaies portant son nom ont été monnayées pendant au moins les neuf années qui sont suivi sa mort.

2 L'article comprend 3 tables qui enregistrent le matériel numismatique sous des aspects différents, des dessins et un catalogue des monnaies. Les monnaies sont reproduites dans les planches 13-19. 
INDEX

Thèmes : 3.2.3. Séleucides, Parthes et Sassanides

\section{AUTEURS}

KARIN MOSIG-WALBURG

Université de Francfort (Allemagne) 